\title{
Factors associated with coliform count in unpasteurized bulk milk
}

\author{
J. C. F. Pantoja, ${ }^{1}$ D. J. Reinemann, and P. L. Ruegg \\ Department of Dairy Science, University of Wisconsin, Madison 53706
}

\section{ABSTRACT}

The objective of this study was to identify factors associated with bulk milk coliform count (CC). Dairy farms $(\mathrm{n}=10)$ were visited once weekly on sequential weekdays over a period of 10 wk. During each visit, in-line drip samplers were used to collect 1 milk sample from 2 points of the milk line (between the receiver jar and milk filters, and after the plate cooler). During the same period that in-line milk samples were collected, university personnel observed milking performance and hygiene and collected liner $(\mathrm{n}=40)$ and teat skin swabs $(\mathrm{n}=40)$. Coliform counts were determined for milk samples and swabs using Petrifilm CC plates (3M, St. Paul, MN). A mixed model was used to assess the association between in-line milk CC (ILCC) and several potential predictor variables. The mean duration of each visit was $73 \mathrm{~min}$ and the time between start of milking and beginning of milk sampling was 154 min. The mean number of cows milked during each visit was 236. For all milk samples $(\mathrm{n}=181)$, geometric mean ILCC was $37 \mathrm{cfu} / \mathrm{mL}$. In-line milk CC varied by farm, ranging from 5 to $1,198 \mathrm{cfu} / \mathrm{mL}$. Rate of fall-offs, rate of cluster washes, outdoor and indoor temperature, indoor humidity, sampling duration, and parity group were unconditionally associated with ILCC but did not enter the final multivariate model. In-line milk $\mathrm{CC}$ was 4 times greater $(115 \mathrm{cfu} / \mathrm{mL})$ when milking machine wash failures occurred compared with ILCC after normal washes $(26 \mathrm{cfu} / \mathrm{mL})$. Pre-filter and postcooler ILCC were not different when milk samples were collected at the beginning ( $<33 \%$ of herd milked) or at mid-milking (33 to $66 \%$ of the herd milked), whereas pre-filter ILCC was less than post-cooler for samples collected at the end of milking ( $>67 \%$ of the herd milked). Geometric mean ILCC (cfu/mL) increased $6.3 \%$ for every $10 \%$ increase in in-line milk SCC (cells/ $\mathrm{mL}$ ). Geometric mean ILCC increased $2.3 \%$ for every $10 \%$ increase in liner $\mathrm{CC}(\mathrm{cfu} / \mathrm{mL})$. Results of this study provide novel information about farm factors associated with CC, as estimated in milk before storage in tankers or bulk tanks, and highlight the importance of proper

Received August 12, 2010.

Accepted February 4, 2011

${ }^{1}$ Corresponding author: jpantoja@wisc.edu and consistent milking machine washes in minimizing bulk milk coliform contamination. The nature of the associations between liner $\mathrm{CC}$, rate of cluster washes, rate of milking units fall-offs, and ILCC indicates that managing and monitoring such events has the potential for improving bacteriological quality of farm bulk milk. Key words: bacterial count, coliforms, milk quality, dairy

\section{INTRODUCTION}

Coliform bacteria are gram-negative non-spore-forming rods and can be found in feces, aquatic environments, soil, and on vegetation. Coliforms are important mastitis pathogens (Hogan and Smith, 2003) and are widely distributed in the farm environment (Hogan et al., 1989; McKinnon et al., 1990; Sanderson et al., 2005). When the total bacteria count of bulk tank milk (BTM) is within regulatory limits, coliforms are mostly destroyed by pasteurization. However, in some circumstances (e.g., pasteurization failures and consumption of unpasteurized milk or dairy products), the presence of coliforms in bulk milk can result in spoilage and severe human disease (Chambers, 2002; Mandell et al., 2005). Some genera such as Klebsiella and Citrobacter are psychrotrophic and may increase 100- to 1,000-fold within a period of $72 \mathrm{~h}$ of milk storage at $<7^{\circ} \mathrm{C}$ (Panes and Thomas, 1968; Griffiths et al., 1987). Shiga toxinproducing strains such as Escherichia coli O157:H7 can cause severe hemorrhagic diarrhea in humans and have been occasionally isolated from BTM (Padhye and Doyle, 1991; Murinda et al., 2002; Karns et al., 2007).

Coliform count (CC) is a nonregulated test that has been used historically to assess milk production practices such as milk refrigeration, milking machine sanitation, and premilking udder hygiene (Guterbock and Blackmer, 1984; Reinemann et al., 1997; Murphy and Boor, 2000; Davidson et al., 2004). Coliform count is a practical indicator of milking hygiene because it is easy and inexpensive to perform (the test can be performed on the farm), and it is often correlated with the population of other bacteria in BTM (Jayarao et al., 2004; Pantoja et al., 2009). However, because coliform bacteria populations can increase rapidly under some conditions, it is important to distinguish between the 
level of initial contamination and increased $\mathrm{CC}$ that may be the result of incubation in the milk handling system after milk harvest.

Coliform bacteria were recovered in $96 \%$ of the BTM samples $(\mathrm{n}=419)$ analyzed in the 2002 National Animal Health Monitoring System dairy survey, of which $40 \%$ had CC between 10 and $100 \mathrm{cfu} / \mathrm{mL}$ (Van Kessel et al., 2004). The mean CC of BTM has been reported to be 31 ( $\mathrm{n}=855$ milk samples; Boor et al., 1998), 37 ( $\mathrm{n}=33,020$ milk samples; Rysanek and Babak, 2005), and $70 \mathrm{cfu} / \mathrm{mL}(\mathrm{n}=504$ milk samples; Jayarao et al., 2004). Goldberg et al. (1991) reported that about 50\% of the 1,203 BTM samples collected from Vermont herds had $\mathrm{CC}>500 \mathrm{cfu} / \mathrm{mL}$, whereas Jayarao et al. (2004) reported that $50 \%$ of 504 BTM samples collected from herds in Pennsylvania had CC $\geq 60 \mathrm{cfu} / \mathrm{mL}$. Most CC reported in recent studies would not meet the regulatory limit of $10 \mathrm{cfu} / \mathrm{mL}$ used in some US states that allow sale of unpasteurized milk. Only $23 \%$ of 853 BTM samples collected from New York herds had $\mathrm{CC} \leq 10 \mathrm{cfu} / \mathrm{mL}$ (Boor et al., 1998). Identification and management of farm factors that determine milk contamination with coliforms has the potential for protecting human health and improving the quality of milk and dairy products.

As farms have modernized, frequent BTM testing has become a common practice for monitoring milk quality and is often used to determine quality premiums. Many dairy processors are increasing the requirements for bacteriological quality of milk, which has presented new challenges to dairy producers. Previous work has indicated that CC of BTM demonstrates great variability (Pantoja et al. 2009). Interpretation of $\mathrm{CC}$ is difficult because factors that determine its variation are not well understood and recommendations are often based on practical experience. Little research has been conducted to quantify BTM coliform contamination from multiple farm sources. Cross-sectional studies have been performed to identify herd-level risk factors associated with BTM bacterial counts (Hutchison et al., 2005; Elmoslemany et al., 2009; Kelly et al., 2009). Results of a recent study including 62 herds in Prince Edward Island, Canada, suggest that herd-level factors related to milking machine sanitation may be important determinants of CC (Elmoslemany et al., 2009). Characteristics of sanitizing solutions such as temperature of the detergent wash, water hardness, and $\mathrm{pH}$ of the alkaline wash were significantly associated with CC (Elmoslemany et al., 2009). Cross-sectional studies are useful for comparing management practices associated with CC among herds but do not identify factors that vary longitudinally within individual farms (e.g., events that occur during milking). Many milking practices can be managed by farmers and an understanding of practices that influence CC would allow farmers to better manage milk quality. The objective of this study was to identify factors associated with $\mathrm{CC}$ on farms that use modern technology for milk harvest, storage, and transport.

\section{MATERIALS AND METHODS}

\section{Farm Selection and Data Collection}

A cohort of 10 dairy farms in Wisconsin was enrolled into the study. Farms were eligible to participate if they were licensed to sell grade-A milk (FDA, 2009) and had adopted modern milking and milk machine cleaning technologies. Each farm was visited 10 times on sequential weekdays and different milking times between June and September 2009. Farms that were visited on any day between Monday and Thursday were visited $8 \mathrm{~d}$ later on the following week, at a different milking time. Farms that were visited on Fridays were next visited on the following Monday. During each visit, in-line drip samplers (Quality Management Inc., Oakdale, MN) were used to collect 1 milk sample from 2 points of the milk line (between the receiver jar and milk filters, and after the plate cooler). In-line milk samples were collected into 2-L sterile plastic bags (Quality Management Inc.) kept in coolers with ice. Milk flow during sampling was controlled using a flow regulator so that approximately $500 \mathrm{~mL}$ of milk was collected during the total sampling time. Upon completion of sampling, 20 $\mathrm{mL}$ of milk was transferred to a sterile plastic vial and refrigerated until arrival to the University of Wisconsin's Milk Quality Laboratory.

During each visit and while in-line milk samples were collected, university personnel observed milking performance and hygiene and collected liner $(\mathrm{n}=40)$ and teat skin swabs $(\mathrm{n}=40)$. Liner swabbing was performed as described by Zadoks et al. (2003). Large obstetric rayon swabs (Puritan Medical Products Company LLC, Guilford, ME) were inserted up to the base of the teat cup and removed using spiral movements while swabbing the inner surface of the liner. Alternate liners were swabbed from consecutive clusters in the parlor. Swabs were kept in sterile plastic vials containing $12 \mathrm{~mL}$ of buffered peptone water (Becton, Dickinson and Company, Sparks, MD). Teat skin swabs were collected from one teat per cow (alternating teats in consecutive cows) by swabbing the teat skin with a cotton swab (Puritan Medical Products Company LLC) from the base to the apex immediately after udder preparation (before unit attachment). Teat skin swabs were transported in sterile plastic vials containing $4 \mathrm{~mL}$ of buffered peptone 
water. Water samples $(20 \mathrm{~mL})$ were collected in sterile plastic vials from 2 hoses in the parlor, after letting water flow for $10 \mathrm{~s}$ from the hose.

\section{Bacteriology and SCC}

Samples were immediately processed upon arrival in the laboratory. Milk, water, liner, and teat skin CC $(\mathrm{cfu} / \mathrm{mL})$ were performed using the Petrifilm CC method (3M, St. Paul, MN). A composite sample from all liner swabs collected on each farm visit was prepared in the laboratory to estimate the population of coliforms on the surface of liners (explanatory variable). This population of coliforms is the community of bacteria that would contribute to the outcome variable, which was measured on in-line milk. Each tube containing a swab dipped in transport medium was vortexed, and the liquid content was transferred to a sterile flask. Subsequently, $1 \mathrm{~mL}$ of the composite sample was used to make serial dilutions using buffered peptone water at 1:10, 1:100, 1:1,000, and 1:10,000. The same method was used to create a composite sample from all teat skin swabs collected on each farm visit.

The in-line milk samples collected on each farm visit (pre-filter and post-cooler) were processed individually and diluted using buffered peptone water at 1:10, 1:100, and 1:1,000. One milliliter of each undiluted and diluted milk, liner, and teat skin samples was plated on Petrifilm CC plates and incubated for $24 \mathrm{~h}$ at $36^{\circ} \mathrm{C}$. Colony-forming units were counted electronically using the Petrifilm Plate Reader (3M). To ascertain the final $\mathrm{CC}$ relative to a dilution series, the count from the plate containing $<150 \mathrm{cfu} / \mathrm{mL}$ was used. When 2 or more plates of the same dilution series had $<150 \mathrm{cfu} /$ $\mathrm{mL}$, the result of the least diluted sample was used. Somatic cell count was determined using the Direct Cell Counter (DeLaval, Tumba, Sweden) for all in-line milk samples that were used to determine CC. Bulk milk CC was also performed in the dairy processors' laboratories using milk from the same tanker (tanker CC) that was loaded while in-line milk samples and milking hygiene observations were collected.

\section{Statistical Analysis}

Study Variables. The outcome variable was in-line milk CC (ILCC), measured in $\log _{10} \mathrm{cfu} / \mathrm{mL}$ (Table 1). Explanatory variables measured for weather conditions were outdoor temperature (measured outside at arrival to the farm, ${ }^{\circ} \mathrm{C}$ ), indoor temperature (measured in the parlor at arrival to the farm, ${ }^{\circ} \mathrm{C}$ ), outdoor relative humidity (\%), and indoor relative humidity (\%).

Explanatory variables measured for characteristics of in-line milk sampling were duration of in-line milk sampling (min); time interval between start of milking and start of in-line milk sampling ( $\mathrm{min}$ ); milking period (beginning $=<33 \%$; middle $=33$ to $66 \%$; end $=67$ to $100 \%$ of the herd milked at the beginning of in-line milk sampling); and in-line milk sampling point (pre-filter or post-cooler).

Explanatory variables that were measured simultaneously with in-line milk sampling and used to study the association between ILCC and hygienic conditions of the parlor, milking equipment, and cows were liner CC (measured in $\left.\log _{10} \mathrm{cfu} / \mathrm{mL}\right)$; hose water CC $\left(\log _{10}\right.$ $\mathrm{cfu} / \mathrm{mL}$ ); teat skin CC (measured in $\log _{10} \mathrm{cfu} / \mathrm{mL}$ ); rate of milking platform washes (frequency at which an entire side of the milking platform was washed divided by the milk sampling time per visit, measured in washes $/ \mathrm{h}$ ); rate of cow defecation on the platform (frequency of cow defecations on the milking platform during the milk sampling time per visit divided by the number of milking units, measured in defecations/milking unit per hour); rate of cluster fall-offs (frequency of fall-offs during the milk sampling time per visit divided by the number of milking units, measured in falls/milking unit per hour); rate of cluster washes (frequency at which all clusters on a side of the parlor were washed by milkers divided by the milk sampling time per visit, measured in washes $/ \mathrm{h}$ ); and number of cows milked during in-line milk sampling. In addition, the following hygiene scores (measured as the proportion of scores dirty and very dirty in a 4 -point scale ranging from clean to very dirty) were performed simultaneously with in-line milk sampling: udder hygiene scores (Schreiner and Ruegg, 2003); rear leg hygiene scores (Schreiner and Ruegg, 2003); teat cup hygiene scores (same scale as udder hygiene scores but used to record cleanliness of the external rubber surface of liner's mouthpiece); and teat end condition scores (Mein et al., 2001; proportion of teats with rough and very rough ring in a 4-point scale ranging from no ring to very rough ring).

Other variables were in-line milk SCC (ILSCC; measured in $\log _{10}$ cells $/ \mathrm{mL}$ ); farm (1 to 10); day of the week (Monday to Friday); parity group milked during a visit (first-lactation cows, $\geq 2$ lactations, or mixed); and milking machine wash failures (yes or no). Wash failures were defined based on the last wash before a visit as failures to reach the normal wash water temperature ( $<20 \%$ of farm's preset temperature), failure to dispense a farm's preset amount of detergent during wash, skipped washes, or lack of water flow through one or more milking units. Wash temperature failures or skipped washes were recorded by reading the farm's temperature recorder chart. Failures to dispense the preset amount of detergent or other failures were reported by the farm staff on the visit day. 
Table 1. Study variables

\begin{tabular}{|c|c|c|}
\hline Variable and abbreviation & Type (unit) & Description \\
\hline In-line milk coliform count (ILCC) & Continuous $\left(\log _{10} \mathrm{cfu} / \mathrm{mL}\right)$ & Outcome variable, performed on in-line milk samples \\
\hline Liner coliform count (liner CC) & Continuous $\left(\log _{10} \mathrm{cfu} / \mathrm{mL}\right)$ & Performed on a composite of 40 liner swabs collected per visit \\
\hline Teat skin coliform count (teat skin CC) & Continuous $\left(\log _{10} \mathrm{cfu} / \mathrm{mL}\right)$ & Performed a composite of 40 teat skin swabs collected per visit \\
\hline Hose water coliform count (hose water CC) & Continuous $\left(\log _{10} \mathrm{cfu} / \mathrm{mL}\right)$ & Performed on water samples collected from hoses in the parlor \\
\hline In-line milk SCC (ILSCC) & Continuous $\left(\log _{10}\right.$ cells $\left./ \mathrm{mL}\right)$ & Performed on the same in-line milk samples that were used for determining ILCC \\
\hline Outdoor temperature & Continuous $\left({ }^{\circ} \mathrm{C}\right)$ & Measured outside the parlor at arrival to farms \\
\hline Indoor temperature & Continuous $\left({ }^{\circ} \mathrm{C}\right)$ & Measured in the parlor at arrival to farms \\
\hline Outdoor humidity & Continuous (\%) & Measured outside the parlor at arrival to farms \\
\hline Indoor humidity & Continuous (\%) & Measured in the parlor at arrival to farms \\
\hline Duration of in-line milk sampling & Continuous (min) & Duration of in-line milk sampling on each farm visit \\
\hline $\begin{array}{l}\text { Interval between start of milking } \\
\text { and start of in-line milk sampling }\end{array}$ & Continuous (min) & Time interval between start of milking and start of in-line milk sampling \\
\hline $\begin{array}{l}\text { Udder hygiene scores } \\
\text { (Schreiner and Ruegg, 2003) }\end{array}$ & $\begin{array}{l}\text { Continuous } \\
\text { (proportion scored } 3 \text { or } 4 \text { ) }\end{array}$ & $\begin{array}{l}1=\text { clean } \\
2=\text { slightly dirty } \\
3=\text { dirty } \\
4=\text { very dirty }\end{array}$ \\
\hline $\begin{array}{l}\text { Rear leg hygiene scores } \\
\text { (Schreiner and Ruegg, 2003) }\end{array}$ & $\begin{array}{l}\text { Continuous } \\
\text { (proportion scored } 3 \text { or } 4 \text { ) }\end{array}$ & $\begin{array}{l}1=\text { clean } \\
2=\text { slightly dirty } \\
3=\text { dirty } \\
4=\text { very dirty }\end{array}$ \\
\hline Teat cup hygiene scores & $\begin{array}{l}\text { Continuous } \\
\text { (proportion scored } 3 \text { or } 4 \text { ) }\end{array}$ & $\begin{array}{l}1=\text { clean } \\
2=\text { slightly dirty } \\
3=\text { dirty } \\
4=\text { very dirty }\end{array}$ \\
\hline $\begin{array}{l}\text { Teat end condition scoring } \\
\text { (Mein et al., 2001) }\end{array}$ & $\begin{array}{l}\text { Continuous } \\
\text { (proportion scored } 3 \text { or } 4 \text { ) }\end{array}$ & $\begin{array}{l}1=\text { no teat end ring } \\
2=\text { smooth teat end ring } \\
3=\text { rough teat end ring } \\
4=\text { very rough teat end ring }\end{array}$ \\
\hline Rate of milking platform washes & Continuous (washes/h) & $\begin{array}{l}\text { Frequency at which an entire side of the milking platform was washed } \\
\text { divided by the time of in-line milk sampling }\end{array}$ \\
\hline Rate of cow defecation on the platform & $\begin{array}{l}\text { Continuous (defecations/ } \\
\text { milking unit per hour) }\end{array}$ & $\begin{array}{l}\text { Frequency of cow defecations on the milking platform during } \\
\text { in-line milk sampling divided by the number of milking units in the parlor }\end{array}$ \\
\hline Rate of cluster fall-offs & $\begin{array}{l}\text { Continuous (falls/milking } \\
\text { unit per hour) }\end{array}$ & $\begin{array}{l}\text { Frequency of fall-offs during in-line milk sampling divided } \\
\text { by the number of milking units in the parlor }\end{array}$ \\
\hline Rate of cluster washes & Continuous (washes/h) & $\begin{array}{l}\text { Frequency at which all clusters on a side of the parlor were washed } \\
\text { divided by the time of in-line milk sampling }\end{array}$ \\
\hline $\begin{array}{l}\text { Number of cows milked during } \\
\text { in-line milk sampling }\end{array}$ & Continuous (number of cows) & Number of cows milked during in-line milk sampling \\
\hline Farm & Categorical & Farms 1 to 10 \\
\hline Day of the week for each visit & Categorical & Monday to Friday \\
\hline Milking period & Categorical & $\begin{array}{l}\text { Beginning }=<33 \% ; \text { middle }=33 \text { to } 66 \% \text {; end }=67 \text { to } 100 \% \\
\text { of the herd milked at the beginning of in-line milk sampling }\end{array}$ \\
\hline In-line milk sampling point & Categorical & Pre-filter or post-cooler \\
\hline Parity group milked during a visit & Categorical & Heifers, cows, or mixed \\
\hline Milking machine wash failure ${ }^{1}$ & Categorical & Yes or no \\
\hline
\end{tabular}

ITash failures were defined based on the last wash before a visit as failures to reach the normal wash water temperature (<20\% of a farm's preset temperature), failure to dispense

a farm's preset amount of detergent during wash, lack of water flow through $>1$ milking unit, or skipped wash. 
Statistical Procedures. The data set was initially screened for errors. The distribution of continuous variables was analyzed using box and normal probability plots. Measures of central tendency (mean and geometric mean) and dispersion (SD) were used to produce summary statistics. Coliform counts $(\mathrm{cfu} / \mathrm{mL}$ ) and SCC (cells $/ \mathrm{mL}$ ) were transformed using base 10 logarithm for analysis. Association among variables was first assessed using the Spearman coefficient of correlation (Pagano and Gauvreau, 2000). Simple linear regression and one-way ANOVA (Pagano and Gauvreau, 2000) were used to test the association between ILCC and each explanatory variable. Variables individually associated with ILCC at a $P$-value $\leq 0.25$, first-order interactions among them and quadratic terms were offered to backward and forward variable selection procedures to construct a final multivariate mixed model (Palta, 2003; PROC MIXED, SAS Institute, 2009). Except for temperature and humidity measurements, correlation among explanatory variables that were offered to variable selection was weak and ranged from -0.30 to 0.21 . Because of the strong correlation found between indoor and outdoor temperature $(\mathrm{r}=0.97)$ and between indoor and outdoor humidity $(\mathrm{r}=0.91)$, these variables were not included simultaneously in variable selection procedures. Potential confounding variables were forced into the final model but inclusion of no variables resulted in substantial changes $(\geq 20 \%)$ in other explanatory variables' coefficients. The final model was as follows:

$$
\begin{gathered}
\text { ILCC }_{\mathrm{ijklmn}}=\beta_{0}+\beta \text { ILSCC }_{\mathrm{ij}}+\beta \text { Liner CC }_{\mathrm{j}}+\text { Farm }_{\mathrm{k}} \\
+ \text { Wash Failure }_{\mathrm{l}}+\text { Milk Sampling Point }_{\mathrm{m}} \\
+ \text { Milking Period }_{\mathrm{n}}+(\text { Milk Sampling Point } \\
\quad \times{\text { Milking Period })_{\mathrm{mn}}+\delta_{\mathrm{j}},}
\end{gathered}
$$

where ILCC was the mean ILCC $\left(\log _{10} \mathrm{cfu} / \mathrm{mL}\right) ; \beta_{0}$ was the intercept; $\beta$ ILSCC $_{i j}$ was the coefficient for ILSCC $\left(\log _{10}\right.$ cells $\left./ \mathrm{mL}\right)$ for the ith in-line milk sample within the $\mathrm{jth}$ visit; $\beta$ Liner $\mathrm{CC}_{\mathrm{j}}$ was the coefficient for liner $\mathrm{CC}\left(\log _{10} \mathrm{cfu} / \mathrm{mL}\right)$ for the jth visit; Farm $_{\mathrm{k}}$ was farm $(\mathrm{k}=1$ to 10$)$; Wash Failure 1 was wash failure (yes $=1$ and no $=0)$; Milk Sampling Point ${ }_{\mathrm{m}}$ was the sampling location (pre-filter $=0$ and post-cooler $=1$ ); Milking Period $_{n}$ was the percentage of the herd milked at the beginning of milk in-line milk sampling $(<33 \%, 33$ to $66 \%$, or 67 to $100 \%$ ); Milk Sampling Point $\times$ Milking Period $_{\mathrm{mn}}$ was the interaction between milk sampling point and milking period; and $\delta_{\mathrm{j}}$ was a random term relative to the effect of visit $\mathrm{j}$, used to model the covariance between the 2 ILCC obtained on the same farm visit. A compound-symmetry covariance structure was used to account for the clustering of 2 ILCC (intraclass correlation $=0.88)$ obtained on the same visit. Thus, the hierarchical structure of the model assumed farm as a fixed effect, clustering of ILCC within visit, and lack of correlation among ILCC obtained in different weeks within herds. The final model (equation [1]) provided the best fit for the data (as assessed using Akaike and Bayesian information criteria) when compared with other hierarchical structures assuming herd as a random effect.

The modeling procedures aforementioned were also performed excluding data from farm 7 because its geometric mean ILCC was much greater as compared with the other farms (Table 2). Because results of the analysis excluding farm 7 indicated no substantial changes in results, the data set including all 10 farms enrolled into the study was used for analysis.

A paired $t$-test (Pagano and Gauvreau, 2000) was used to test the hypothesis that means ILCC and tanker CC were not equal. Both variables were further dichotomized into "increased" and "not increased" using a threshold of $160 \mathrm{cfu} / \mathrm{mL}$ (Pantoja et al., 2009) and the agreement between them was assessed using Kappa statistics (Pagano and Gauvreau, 2000). Statistical significance was defined as $P \leq 0.05$. Statistical analysis was performed with SAS version 9.2 (SAS Institute, 2009).

\section{RESULTS}

\section{Farm Characteristics}

The mean herd size was 1,205 lactating cows (205 to 3,552$)$. For most farms, sand was the primary bedding source, cows were milked in parallel parlors, and milk was loaded directly into truck-tankers (Table 2). Farms used modern technology including electronic milk meters $(\mathrm{n}=10)$, plate milk coolers $(\mathrm{n}=10)$, milk and wash water temperature control charts $(\mathrm{n}=10)$, computerized milking equipment wash controllers $(\mathrm{n}=$ 7), and automatic unit removers ( $\mathrm{n}=10$ farms). Milk line filters were installed between the receiver jar and plate milk coolers of all farms and were replaced before every milking. Cows were milked 3 times per day, except for one farm that milked twice daily. A milking machine cleaning-in-place procedure (CIP) consisting of post-milking rinse, detergent wash, acid rinse and pre-milking sanitation was set to be performed after each milking on all farms. All farms had milking equipment inspected and maintained by manufacturers' authorized dealers at least twice per year. Although parlor work routines differed among farms, teats were always disinfected before and after milking (9 farms used iodine and 1 farm used chlorhexidine-based dip solutions) and dried with individual cloth towels before 
Table 2. Farm characteristics, sorted by herd size

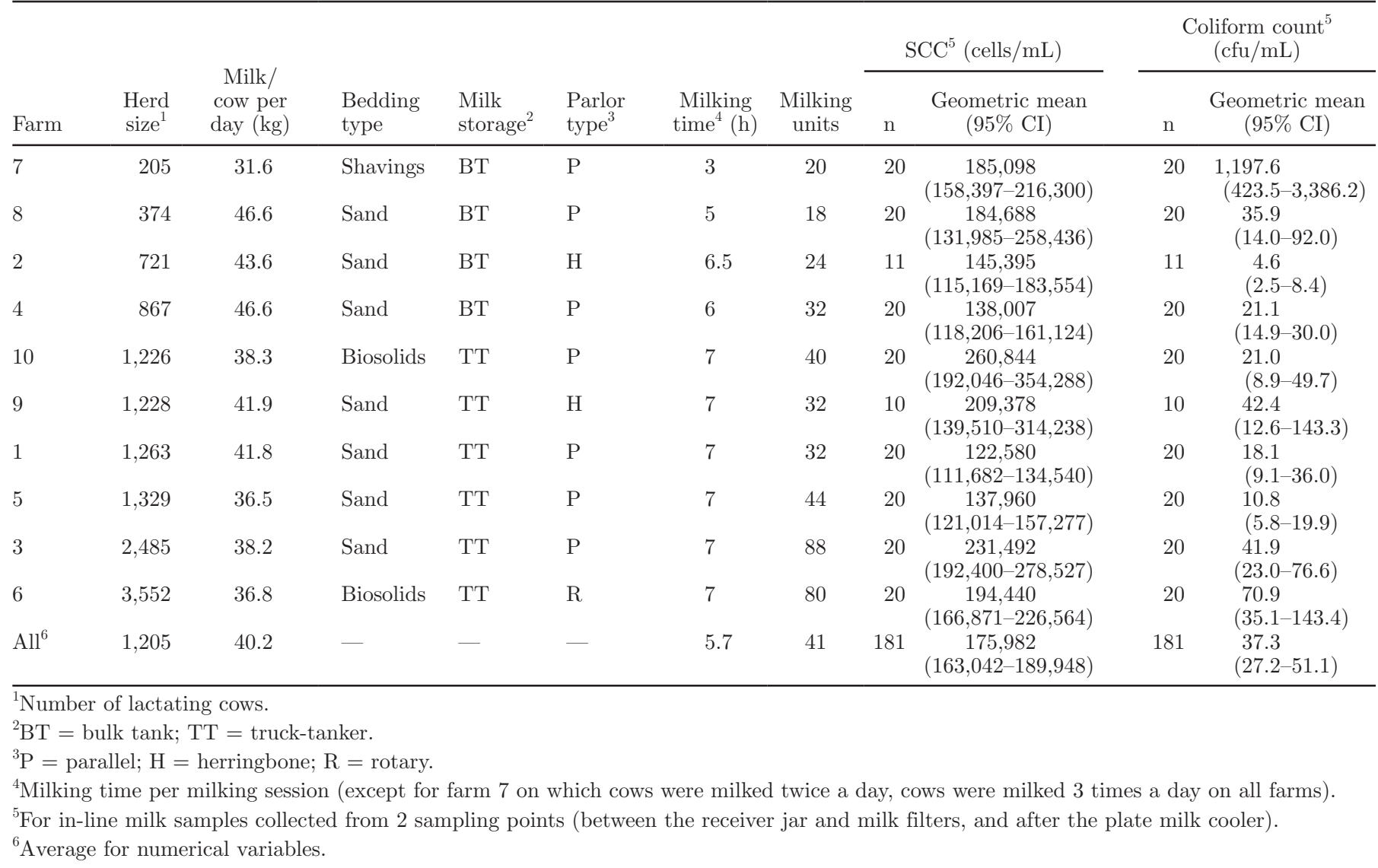

cluster attachment. Towels were machine washed and dried between every milking. No milk loads produced on visit days had antibiotics detected (as reported by the dairy processors' laboratories).

Hose water in the parlor was mixed with disinfectant solutions on all farms and was used to wash clusters and the milking platform during milking. Washing of clusters and milking platform was a common practice observed during milking. With exception of 2 farms, all clusters from each side of the parlor were washed by milkers at rates ranging from 0.5 to 5.3 times per $\mathrm{h}$ (Table 3). For all farms (except for the farm with a rotary parlor, on which milking stalls were automatically washed every time they passed by a fixed water spray), milkers washed the entire side of the milking platform at rates ranging from 0.1 to 4.0 times per h (Table 3). Fall of clusters to the platform occurred on 9 farms (Table 3). One farm with a herringbone parlor had clusters attached to a mechanical arm that prevented them from falling to the platform. On half of the farms, fall of milking clusters occurred at a rate of 0.1 fall/milking unit per hour and was followed by either reattachment to cows (with previous cleaning or not) or cessation of milking.

\section{Descriptive Statistics and Associations}

The data set was planned to include 200 observations (ILCC measurements) collected during 100 farm visits. Nonetheless, the final data set used for analysis consisted of 181 observations because 1 visit was not performed (generating 2 missing values) and 17 postcooler milk samples from 2 farms could not be collected. The mean duration of each visit was $73 \mathrm{~min}(\mathrm{SD}=17)$ and the time between start of milking and beginning of milk sampling was $154 \mathrm{~min}(\mathrm{SD}=131)$. On average, 236 ( $\mathrm{SD}=147$ ) cows were milked during each visit.

For all milk samples, geometric mean (95\% CI) ILCC and ILSCC were $37.3 \mathrm{cfu} / \mathrm{mL}(\mathrm{CI}=27.2$ to 51.1$)$ and 175,982 cells $/ \mathrm{mL}(\mathrm{CI}=163,042$ to 189,948$)$, respectively (Table 2). In-line milk $\mathrm{CC}$ varied by farm $(P<$ 0.01 ), ranging from 4.6 to $1,197.6 \mathrm{cfu} / \mathrm{mL}$ (Table 3 ), and was not different by day of the week $(P=0.49)$.

Unconditional Associations. Rate of fall-offs, rate of cluster washes, outdoor and indoor temperature, indoor humidity, sampling duration, and parity group were offered to variable selection procedures $(P$ $<0.25)$ but did not enter the final multivariate model (Table 4). An increase in the rate of cluster fall-offs was 
Table 3. Mean (95\% CI) for milking time events, liner coliform count, and in-line milk coliform count (ILCC) by farm, sorted by ILCC

\begin{tabular}{lcccccc}
\hline & & & & & \multicolumn{2}{c}{ ILCC $^{5}(\mathrm{cfu} / \mathrm{mL})$} \\
\cline { 5 - 7 } Farm & $\begin{array}{c}\text { Rate of milking } \\
\text { units fall-offs }^{1}\end{array}$ & $\begin{array}{c}\text { Rate of } \\
\text { cluster washes }^{2}\end{array}$ & $\begin{array}{c}\text { Rate of } \\
\text { platform washes }^{3}\end{array}$ & $\begin{array}{c}\text { Geometric mean } \\
\text { liner CC }\end{array}(\mathrm{cfu} / \mathrm{mL})$ & $\mathrm{n}$ & Geometric mean \\
\hline 2 & $0.1(0.0-0.1)$ & $0.5(0.1-0.9)$ & $0.9(0.4-1.4)$ & $13.2(9.0-19.2)$ & 11 & $4.6(2.5-8.4)$ \\
5 & $0.4(0.3-0.4)$ & $2.8(2.0-3.6)$ & $1.6(1.3-1.8)$ & $6.6(3.6-11.9)$ & 20 & $10.8(5.8-19.9)$ \\
1 & $0.2(0.1-0.2)$ & $5.1(4.5-5.7)$ & $2.0(1.6-2.4)$ & $58.2(14.3-236.5)$ & 20 & $18.1(9.1-36.0)$ \\
10 & $0.1(0.0-0.1)$ & $0.5(0.2-0.8)$ & $1.0(0.6-1.3)$ & $24.6(10.7-56.4)$ & 20 & $21.0(8.9-49.7)$ \\
4 & $0.1(0.1-0.1)$ & $1.2(0.7-1.8)$ & $1.4(0.9-1.9)$ & $37.4(12.5-111.8)$ & 20 & $21.1(14.9-30.0)$ \\
8 & $0.1(0.1-0.2)$ & $0.0(0.0-0.0)$ & $4.0(2.9-5.1)$ & $51.4(15.6-169.3)$ & 20 & $35.9(14.0-92.0)$ \\
3 & $0.0(0.0-0.0)$ & $5.3(4.4-6.2)$ & $2.1(0.7-3.4)$ & $14.2(5.8-34.6)$ & 20 & $41.9(23.0-76.6)$ \\
9 & $0.1(0.0-0.1)$ & $0.0(0.0-0.0)$ & $0.1(0.0-0.2)$ & $31.9(14.3-71.2)$ & 10 & $42.4(12.6-143.3)$ \\
6 & $0.2(0.2-0.3)$ & $3.6(3.5-3.7)$ & $3.6(3.5-3.7)$ & $34.4(11.4-103.3)$ & 20 & $70.9(35.1-143.4)$ \\
7 & $0.3(0.3-0.4)$ & $0.6(0.3-0.8)$ & $0.7(0.3-1.1)$ & $13.1(4.2-40.5)$ & 20 & $1,197.6(423.5-3,386.2)$ \\
All & $0.2(0.1-0.2)$ & $2.0(1.7-2.3)$ & $1.7(1.5-2.0)$ & $23.5(17.1-32.4)$ & 181 & $37.3(27.2-51.1)$ \\
\hline
\end{tabular}

\footnotetext{
${ }^{1}$ Frequency of fall-offs during milk sampling time per visit divided by the number of milking units (falls/milking unit per hour).

${ }^{2}$ Frequency at which all clusters on a side of the parlor were washed divided by the milk sampling time per visit (washes/h).

${ }^{3}$ Frequency at which an entire side of the milking platform was washed divided by the milk sampling time per visit (washes/h).

${ }^{4}$ For swabs collected from liners' inner surface (within the teacup).

${ }^{5}$ For in-line milk samples collected from 2 sampling points (between the receiver jar and milk filters, and after the plate milk cooler).
}

unconditionally associated with an increase in ILCC $(P$ $=0.02)$, whereas a negative association was observed between ILCC and rate of cluster washes (statistical tendency; $P=0.10$; Table 4 ). A positive association was observed between indoor temperature and ILCC (statistical tendency; $P=0.06$; Table 4). As compared with first-lactation cows, mean ILCC was greater when older cows or mixed groups were milked during the observation time $(P=0.03$, Table 4$)$. Farm-adjusted mean ILSCC was different between first-lactation cows $(133,888)$ and cows with $\geq 2$ lactations $(195,735)$, or mixed groups $(179,935$ cells $/ \mathrm{mL})(P<0.01)$.

Conditional Associations. Milking period, milk sampling point, milking machine wash failures, liner CC, ILSCC, and the interaction between sampling point and milking period remained in the final multivariate model $(P<0.05$; Table 5$)$. Nineteen wash failures occurred on 6 farms, of which 10 (53\%) occurred on 1 farm. Wash failures occurred because of failure to dispense the preset amount of detergent $(n=9)$, failure to reach maximum water temperature $(\mathrm{n}=6)$, lack of water flow through one or more milking units $(\mathrm{n}=2)$, and skipped wash $(\mathrm{n}=2)$. In-line milk $\mathrm{CC}$ was 4 times greater $(114.7 \mathrm{cfu} / \mathrm{mL})$ when wash failures occurred compared with ILCC after normal washes $(26.4 \mathrm{cfu} /$ $\mathrm{mL}$; Table 5). The effect of sampling point on the mean ILCC depended on milking period $(P=0.04$; Figure 1). Pre-filter and post-cooler ILCC were not different when collected at the beginning or middle of milking, whereas pre-filter ILCC was less than post-cooler when collected at the end of milking $(P<0.01$; Figure 1$)$. Although no significant differences in ILCC were observed among samples collected at the beginning, middle or end of milking $(P>0.21)$, pre-filter ILCC numerically decreased from beginning to middle and end of milking
(Figure 1). Mean ILCC (cfu/mL) increased $6.3 \%$ for every $10 \%$ increase in ILSCC (cells $/ \mathrm{mL} ; P<0.01$; Table 5 ). Mean ILCC increased $2.3 \%$ for every $10 \%$ increase in liner $\mathrm{CC}(\mathrm{cfu} / \mathrm{mL}$; Table 5$)$.

Of 48 paired CC (both tanker and in-line milk samples collected on the same day), the mean tanker $\mathrm{CC}$ was 3.5 times greater $(77.8 \mathrm{cfu} / \mathrm{mL})$ than ILCC $(22.4 \mathrm{cfu} / \mathrm{mL})(P<0.01)$. The agreement between dichotomized ILCC and tanker CC was poor (Kappa $=0.24 ;$ Figure 2). Of "not increased" ILCC $(<160$ $\mathrm{cfu} / \mathrm{mL} ; \mathrm{n}=43), 17(40 \%)$ were "increased" based on tanker milk samples. However, none of the "increased" ILCC were defined as "not increased" based on tanker milk samples.

\section{DISCUSSION}

The primary objective of this study was to identify management factors associated with milk CC. We chose to accomplish this goal by simultaneously measuring farm factors and collecting milk samples as milk passed through the milking machine. In-line sampling was developed in the late 1980s and has contributed significantly to the identification of farm sources of BTM bacterial contamination (McKinnon et al., 1988, 1990; Godden et al., 2002). As opposed to a previous study (Elmoslemany et al., 2009) in which herd-level factors were measured at a fixed point in time and outcomes were ascertained using multiple bacterial counts of BTM collected in different days, in the present study both explanatory and outcome variables were measured in real time within individual farms. In theory, this strategy would allow a more precise quantification of relationships between management factors and CC before storage of milk, and also identification of events 
Table 4. Unadjusted coefficients and geometric mean in-line milk coliform count (ILCC; cfu/mL) for all explanatory variables that were individually associated with ILCC $(P<0.25)$

\begin{tabular}{|c|c|c|c|}
\hline Variable & $\mathrm{n}$ & Coefficient & $P$-value \\
\hline \multicolumn{4}{|l|}{ Continuous variables } \\
\hline Rate of cluster fall-offs (falls/milking unit per hour) & 181 & 1.07 & 0.02 \\
\hline Rate of cluster washes ${ }^{1}$ (washes $\left./ \mathrm{h}\right)$ & 181 & -0.05 & 0.10 \\
\hline Temperature outside parlor $\left({ }^{\circ} \mathrm{C}\right)$ & 181 & 0.04 & 0.13 \\
\hline Temperature in the parlor $\left({ }^{\circ} \mathrm{C}\right)$ & 181 & 0.04 & 0.06 \\
\hline Indoor relative humidity (\%) & 181 & 0.01 & 0.13 \\
\hline Milk in-line sampling duration (min) & 181 & -0.01 & 0.06 \\
\hline Liner coliform count $\left(\log _{10} \mathrm{cfu} / \mathrm{mL}\right)$ & 181 & 0.23 & $<0.01$ \\
\hline In-line milk SCC $\left(\log _{10}\right.$ cells/mL) & 181 & 0.80 & $<0.01$ \\
\hline \multicolumn{2}{|l|}{ Categorical variables } & $\operatorname{ILCC}(\mathrm{CI})$ & $P$-value \\
\hline \multicolumn{3}{|l|}{ Wash failures $^{2}$} & $<0.01$ \\
\hline No & 144 & $20.5(15.7-26.7)$ & \\
\hline Yes & 37 & $385.1(382.1-388.0)$ & \\
\hline \multicolumn{3}{|l|}{ Milk sampling point } & 0.13 \\
\hline Pre-filter & 99 & $29.9(19.6-45.5)$ & \\
\hline Post-cooler & 82 & $48.7(30.3-78.1)$ & \\
\hline \multicolumn{3}{|l|}{ Milking period ${ }^{3}$} & 0.16 \\
\hline Beginning & 77 & $53.2(28.9-98.0)$ & \\
\hline Middle & 43 & $30.3(18.2-50.4)$ & \\
\hline End & 61 & $27.5(18.8-40.3)$ & \\
\hline \multicolumn{3}{|l|}{ Parity group } & 0.03 \\
\hline First lactation & 26 & $14.8(5.8-38.1)$ & \\
\hline$\geq 2$ lactations & 47 & $31.2(19.7-49.2)$ & \\
\hline Mixed & 108 & $50.3(32.9-77.0)$ & \\
\hline \multicolumn{3}{|l|}{ Farm } & $<0.01$ \\
\hline
\end{tabular}

${ }^{1}$ Frequency at which all clusters on a side of the parlor were washed divided by the milk sampling time per visit. ${ }^{2}$ Wash failures were defined based on the last wash before a visit as failures to reach the normal wash water temperature ( $<20 \%$ of a farm's preset temperature), failure to dispense a farm's preset amount of detergent during wash, lack of water flow through $\geq 1$ milking unit, or skipped wash.

${ }^{3}$ Beginning $=<33 \%$; middle $=33$ to $66 \%$; end $=67$ to $100 \%$ of the herd milked at the beginning of in-line milk sampling.

that occur at milking time that have not been previously studied as potential predictors of CC.

Results of this study suggest that events that occur at milking may be important predictors of ILCC. The rate of clusters fall-offs was positively associated with the mean ILCC. In spite of being frequently washed, milking platforms had substantial amounts of feces during milking, and when units fell, they were usually reattached to teats without further cleaning. This may have introduced dirt and feces into the milk. After each cow was milked, clusters hung with the liner opening facing down and were frequently washed using water containing disinfectant solutions. A negative relationship was observed between the rate of cluster washes and ILCC. Although both rate of milking unit fall-offs and rate of cluster washes were only moderately associated with ILCC and did not remain in the final model, associations were biologically plausible and both factors can be managed by farmers. The association observed between liner CC and ILCC suggests that handling of clusters during milking is important to minimize coliform contamination of milk. Sources of contamination of the inner liner wall observed during the study include unit- fall-offs, contact with cows' legs and splashing due to movement of cows. If it is assumed that liner CC is an indirect measurement of multiple sources of milk coliform contamination, strategies to keep liners protected from cows' legs and dirt resulting from splashing should be encouraged. For example, 2 farms used a system in which individual clusters were automatically lowered to a level below the milking platform after milking each cow, protecting them from splashing and contact with cows' legs. Evaluation of such strategies using experimental designs may be warranted.

We observed a positive association between SCC and $\mathrm{CC}$, which has been consistently reported in previous studies (Goldberg et al., 1991; Jayarao et al., 2004; Rysanek and Babak, 2005; Pantoja et al., 2009) and suggests that milking of mastitic cows can increase CC. During the course of this study, farmers frequently asked whether milking of mastitic cows could cause sudden increases ("spikes") in CC. It is theoretically possible for a single infected cow to cause an increased BTM CC. Mammary glands experimentally infected with Escherichia coli have been demonstrated to shed as many as $10^{5}$ to $10^{8} \mathrm{cfu} / \mathrm{ml}$ during short periods 
Table 5. Adjusted coefficients and least squares means in-line milk coliform count (ILCC; cfu/mL) for all explanatory variables that remained in the final multivariate model

\begin{tabular}{|c|c|c|c|}
\hline Variable & $\mathrm{n}$ & Coefficient & $P$-value \\
\hline \multicolumn{4}{|l|}{ Continuous variables } \\
\hline Liner coliform count $\left(\log _{10} \mathrm{cfu} / \mathrm{mL}\right)$ & 181 & 0.24 & $<0.01$ \\
\hline In-line milk SCC $\left(\log _{10}\right.$ cells $\left./ \mathrm{mL}\right)$ & 181 & 0.65 & $<0.01$ \\
\hline Categorical variables & \multicolumn{2}{|r|}{$\mathrm{ILCC}^{2}$} & \multirow{5}{*}{$\begin{array}{l}<0.01 \\
<0.01\end{array}$} \\
\hline Farm & & & \\
\hline Wash failures $^{1}$ & & & \\
\hline No & 144 & $26.4(18.1-38.6)$ & \\
\hline Yes & 37 & $114.7(42.1-312.0)$ & \\
\hline \multirow{2}{*}{\multicolumn{3}{|c|}{ Milk sampling point (milking period = beginning) }} & 0.04 \\
\hline & & & \\
\hline Pre-filter & 41 & $57.1(30.7-106.1)$ & \\
\hline Post-cooler & 36 & $69.8(37.2-131.2)$ & \\
\hline \multicolumn{4}{|c|}{ Milk sampling point $(\operatorname{milking}$ period $=$ middle $)$} \\
\hline Pre-filter & 24 & $47.1(21.6-102.6)$ & \\
\hline Post-cooler & 19 & $61.9(28.1-136.6)$ & \\
\hline \multicolumn{4}{|c|}{ Milk sampling point $($ milking period $=$ end $)$} \\
\hline Pre-filter & 34 & $34.8(18.4-65.9)$ & \\
\hline Post-cooler & 27 & $68.6(35.8-131.6)$ & \\
\hline
\end{tabular}

${ }^{1}$ Wash failures were defined based on the last wash before a visit as failures to reach the normal wash water temperature ( $<20 \%$ of a farm's preset temperature), failure to dispense a farm's preset amount of detergent during wash, lack of water flow through $\geq 1$ milking unit, or skipped wash.

${ }^{2}$ Geometric mean and 95\% CI.

${ }^{3}$ Beginning $=<33 \%$; middle $=33$ to $66 \%$; end $=67$ to $100 \%$ of the herd milked at the beginning of in-line milk sampling.

(Erskine and Bartlett, 1993; Van Werven et al., 1997). According to Marshall (1991), 10 L of milk containing $10^{8} \mathrm{cfu} / \mathrm{mL}$ will contribute $10^{12} \mathrm{cfu}$ to BTM. When added to $20,000 \mathrm{~L}$ of milk (the volume of a modern milk tanker), the total bacterial count of that milk would be increased by $50,000 \mathrm{cfu} / \mathrm{mL}$. Nonetheless, we were not able to quantify the effect of milking individual cows with coliform mastitis using observational research performed on commercial dairy farms.

Based on the study of Barkema et al. (1999), it may be hypothesized that the association found between ILSCC and ILCC was partially a result of herd-specific factors (e.g., farms with greater BTM SCC may have older and less efficient milking equipment or dirtier cows, and therefore, greater ILCC). Although that study was cross-sectional and analyzed at the herd level, estimates of the relationship between ILSCC and ILCC presented herein were farm-adjusted (farm was a fixed effect in the final multivariate model) and most likely reflect longitudinal variation within herds that are quite similar in terms of management styles and mean ILSCC (Table 2). The fact that both ILCC and ILSCC were least when first-lactation cows were milked during the observation time (compared with older cows or mixed pens) exemplifies sources of within-herd variation found in this study and suggests that further investigations of a possible causal relationship between coliform mastitis and ILCC are warranted.
The strong association between milking machine wash failures and ILCC observed in this study agrees with a previous work (Elmoslemany et al., 2009) and highlights the importance of milking machine sanitation in minimizing BTM bacterial contamination (Palmer, 1980; Reinemann et al., 1993; Chambers, 2002). Results of a case-control study including 62 herds in Prince Edward Island, Canada, suggested that herd-level factors related to milking machine sanitation had the greatest biological associations with CC (Elmoslemany et al., 2009). The probability of herds being classified as CC "cases" (at least $4 \mathrm{CC}>50 \mathrm{cfu} / \mathrm{mL}$ out of the last 6 tests performed every other week) was decreased when detergent wash temperature was classified as "high," a water softener was used and pipeline alkaline wash alkalinity was "moderate," compared with "control herds" (Elmoslemany et al., 2009).

When milking equipment CIP procedures are performed using hot water $\left(\geq 70^{\circ} \mathrm{C}\right)$, the microflora recovered from the pipeline surface is mostly composed of thermoduric bacteria such as micrococci, coryneforms, and aerobic spore-forming rods. However, gram-negative rods and streptococci may become the dominant species recovered from the pipeline surface on farms in which cleaning procedures were carried out at lesser temperatures (Jackson and Clegg, 1965; Thomas et al., 1966, 1971). When cleaning failures occur, residual soil may facilitate bacterial attachment, survival, and 


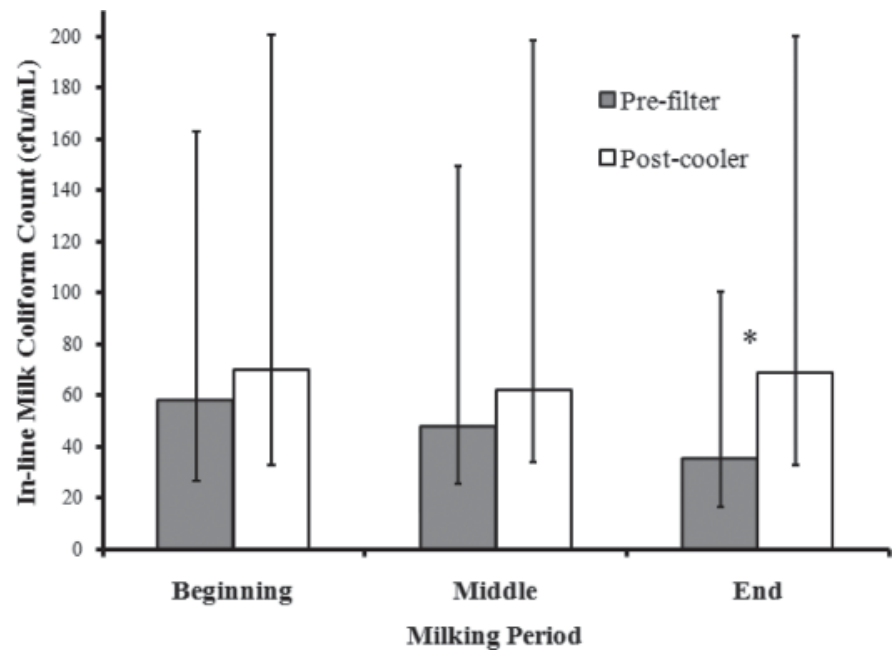

Figure 1. Adjusted geometric mean coliform count and 95\% CI for milk samples collected from drip samplers installed between the receiver jar and milk filter (pre-filter) and after the plate cooler (postcooler). Milking period was defined as follows: beginning: $<33 \%$; middle: 33 to $66 \%$; end: 67 to $100 \%$ of the herd milked at the beginning of in-line milk sampling. Asterisk indicates statistically significant difference $\left(P<0.05\right.$ based on the analysis using $\log _{10}$-transformed coliform counts) between pre-filter and post-cooler milk samples.

growth (Reinemann et al., 1993). Although most farms used electronic wash controllers programmed to automatically execute wash cycles between all milkings, failures to dispense the preset amount of detergent do occur because of machine and human errors. Water temperature is a critical factor that determines inactivation and removal of bacteria from equipment surfaces during milking machine sanitation (Reinemann et al.,

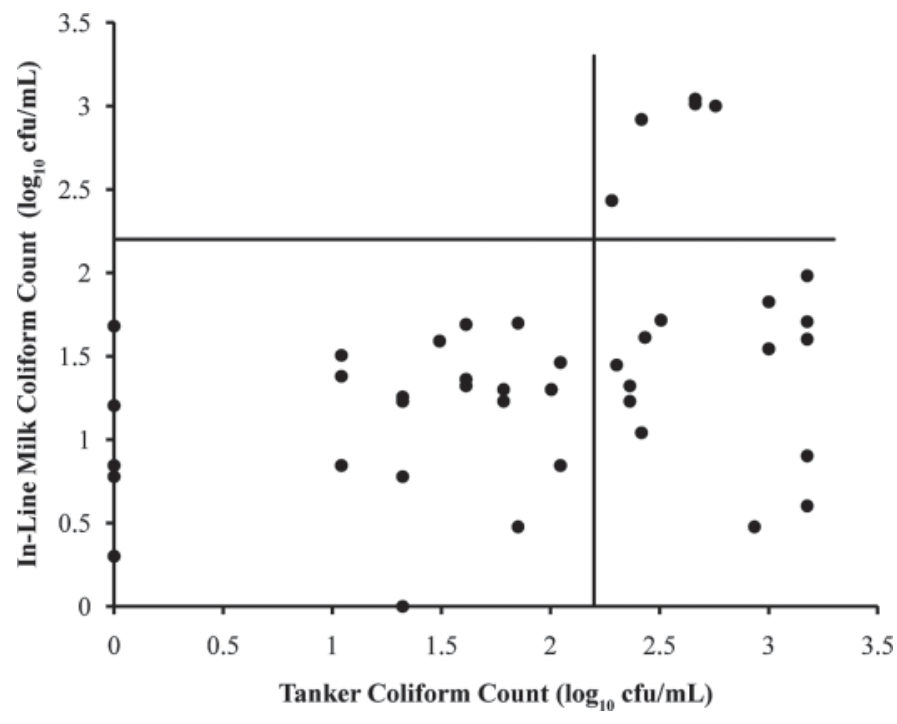

Figure 2. Agreement between in-line milk coliform count (ILCC; collected between the receiver jar and milk filters and after the plate cooler) and tanker coliform count (for milk samples collected at the plant intake). Gridlines represent a threshold of $160 \mathrm{cfu} / \mathrm{mL}$ used to distinguish "increased" from "not increased" ILCC.
1993). Farmers often have difficulty keeping a consistent amount of hot water available for proper washing of the milking system. In addition, due to the intense milking schedule observed on most farms (Table 2), CIP procedures are sometimes skipped. It is possible that reporting of wash failures was susceptible to recall bias because 11 wash failures were reported by farmer personnel based on visual observations or readings of automatic wash-controllers. Nonetheless, the authors believe that introduction of such bias was unlikely because failures were reported on the same day as they occurred (previous milking) or confirmed on farm notebooks used to record such events. Although CIP procedures performed on most participant farms were according to recommended standards (NMC, 2004), results of this study suggest that maintaining consistent milking machine wash procedures can be a challenge in modern dairy farms and has the potential for minimizing coliform contamination of BTM.

Using a sample of 8 small herds (85-135 cows) in the UK, McKinnon et al. (1990) reported an increase in total bacteria count of $3,000 \mathrm{cfu} / \mathrm{mL}$ from milk samples collected at the claw as compared with samples collected at the end of the pipeline. It is possible for coliforms to incubate on equipment surfaces during milking but results of this study showed that ILCC of samples collected at the end of milking was not greater than that of samples collected at the beginning or mid milking, indicating that incubation in the milking machine did not contribute to increased CC. The difference between ILCC collected before milk filters and after the plate cooler depended on milking period. When milk samples were collected at the beginning of milking, post-cooler ILCC was numerically greater than pre-filter, which indicates that the milk filter or plate cooler might have been the source of a modest increase in CC. The milk filter is the only place in the milk handling system in which milk is forced through a large number of very small passages. The increase in $\mathrm{CC}$ in milk passing through a contaminated device such as a milk filter is likely a complex interaction between soil loading, incubation rates, biofilm formation, and bacteria shedding dynamics and is an area of interest for future studies. However, post-cooler ILCC remained relatively constant when collected at beginning, middle, or end of milking, whereas a reduction (not statistically but perhaps biologically significant) was observed for pre-filter ILCC from beginning to end of milking (Figure 1). The difference between pre-filter and postcooler ILCC was statistically significant when milk was collected at the end of milking, but contrary to expectation, the difference was due to a decrease in pre-filter ILCC rather than an increase in post-cooler ILCC. The explanation for this decreasing trend requires further 
investigation. It is important to note that "milking period" was defined based on the proportion of the herd milked at the time of in-line milk sampling, and not based on the milking duration in hours. Because some farms had shorter milking durations than others, "end of milking" may indicate $6 \mathrm{~h}$ of milking for a large dairy that milked for $7 \mathrm{~h}$, whereas it may indicate $2.5 \mathrm{~h}$ of milking for a small dairy that milked for $3 \mathrm{~h}$.

None of the variables measured to estimate cow's cleanliness (udder and rear leg scoring and teat skin CC) were associated with ILCC. These findings disagree with the study of Elmoslemany et al. (2009), who reported that herds in which cows were milked with dirty legs or teats were more likely to be classified as CC cases (at least 4 BTM CC $>50 \mathrm{cfu} / \mathrm{mL}$ out of the last 6 tests performed every other week) than herds in which cows were milked with clean legs or teats. Although cow cleanliness scoring systems may be useful for troubleshooting CC problems at the herd level (making comparisons among herds), results of the present study did not provide evidence that udder or rear leg cleanliness scoring can predict CC changes when assessments are made repeatedly (at 8-d intervals) within individual herds. Even though substantial variation existed in udder or rear leg scoring among visits (data not shown), milkers were very well trained for the group of farms participating in this study and perhaps the effectiveness of pre-milking teat disinfection overcame any changes in cow hygiene that might have influenced CC.

It is important to recognize that both ILCC and the occurrence of milking machine wash failures were much greater for farm 7 compared with the other farms. Thus, the inclusion of data from farm 7 in the model might have resulted in associations between ILCC and explanatory variables that would not be valid for the other farms. To further study this issue, the models were repeated without farm 7. Except for farm, the same explanatory variables remained in the final multivariate model and associations were of the same direction and similar magnitude, indicating that the original analysis resulted in estimates that could confidently be extrapolated to the cohort of farms included in this study.

As a second part of the analysis, it was observed that mean ILCC was less than tanker CC. This comparison should be interpreted with caution because ILCC was collected during an average of $73 \mathrm{~min}$, whereas tanker $\mathrm{CC}$ was estimated using milk from an entire load (representing a greater fraction of milking). In addition, CC performed in the dairy processors' laboratories were considered "zero" when results were $<15 \mathrm{cfu} / \mathrm{mL}$ and considered $1,500 \mathrm{cfu} / \mathrm{mL}$ when counts were $>1,500 \mathrm{cfu} /$ $\mathrm{mL}$. This introduced bias toward both over- and under- estimating the difference between ILCC and tanker CC. Despite these limitations, none of the "increased" ILCC were defined as "not increased" based on tanker milk samples, indicating that the observation was not likely a random event. Incubation of coliform bacteria during milk storage and transport in modern tankers on CC has not been studied and is a subject of importance for future studies. Coliform counts performed after milk transport to dairy processors may not be representative of milk at the moment of production and this may be biasing interpretation of CC made by farmers and dairy consultants.

\section{CONCLUSIONS}

For modern dairy farms similar to those included in this study, CC of BTM seems to be determined by a complex interaction of factors. Several management factors were associated with CC. Milking machine wash failures were strongly associated with ILCC, which suggests that proper and consistent washes play a fundamental role in minimizing BTM contamination with coliforms. The nature of the associations between liner $\mathrm{CC}$, rate of cluster washes, rate of milking units falloffs, and ILCC indicates that monitoring such events and further evaluation of their effects has the potential for improving bacteriological quality of BTM. Coliform counts determined for milk obtained from tankers at the plant intake were greater than CC obtained before loading. Bacterial contamination and multiplication in milk stored and transported into modern tankers has not been studied and deserves further investigation.

\section{ACKNOWLEDGMENTS}

This study was funded by the USDA's multistate project NE1028. We are grateful to the farmers and staff who willingly cooperated with this study. We thank Marcelo Armelin Silva of Ceva Sante Animale, Sao Paulo, Brazil, and Carol Hulland, Tonia L. Peters, Carolina Pinzon, Leane Oliveira, and Ana Carolina Rodrigues of the University of Wisconsin, Madison, for their help with laboratory work and data collection. We also thank Quality Management Inc. (Oakdale, MN) for kindly providing the drip samplers, and 3M (St. Paul, MN) for donating the Petrifilms that were used in this study.

\section{REFERENCES}

Barkema, H. W., J. D. Van der Ploeg, Y. H. Schukken, T. J. G. M. Lam, G. Benedictus, and A. Brand. 1999. Management style and its association with bulk milk somatic cell count and incidence rate of clinical mastitis. J. Dairy Sci. 82:1655-1663.

Boor, K. J., D. P. Brown, S. C. Murphy, S. M. Kozlowski, and D. K. Bandler. 1998. Microbiological and chemical quality of raw milk in New York State. J. Dairy Sci. 81:1743-1748. 
Chambers, J. V. 2002. The microbiology of raw milk. Pages 39-90 in Dairy Microbiology Handbook. 3rd ed. R. K. Robinson, ed. John Wiley \& Sons Inc., New York, NY.

Davidson, P. M., L. A. Roth, and S. A. Gambrel-Lenarz. 2004. Coliform and other indicator bacteria. Pages 187-226 in Standard Methods for the Examination of Dairy Products. 17th ed. H. M. Wehr and J. F. Frank, ed. Am. Public Health Assoc., Washington, DC.

Elmoslemany, A. M., G. P. Keefe, I. R. Dohoo, and B. M. Jayarao. 2009. Risk factors for bacteriological quality of bulk tank milk in Prince Edward Island dairy herds. Part 2: Bacteria count-specific risk factors. J. Dairy Sci. 92:2644-2652.

Erskine, R. J., and P. C. Bartlett. 1993. Serum concentrations of copper, iron, and zinc during Escherichia coli-induced mastitis. J. Dairy Sci. 76:408-413.

FDA. 2009. Grade "A" Pasteurized Milk Ordinance, 2009 rev. Accessed Apr. 28, 2010. http://www.fda.gov/downloads/Food/ FoodSafety/Product-SpecificInformation/MilkSafety/National ConferenceonInterstateMilkShipmentsNCIMSModelDocuments/ UCM209789.pdf.

Godden, S., R. Bey, R. Farnsworth, J. Reneau, and M. Lavalle. 2002 Field validation of a milk line sampling device for monitoring milk quality and udder health. J. Dairy Sci. 85:1468-1475.

Goldberg, J. J., J. W. Pankey, P. A. Drechslesr, P. A. Murdough, and D. B. Howard. 1991. An update survey of bulk tank milk quality in Vermont. J. Food Prot. 54:549-553.

Griffiths, M. W., J. D. Phillips, and D. D. Muir. 1987. Effect of lowtemperature storage on the bacteriological quality of raw milk. Food Microbiol. 4:285-291.

Guterbock, W. M., and P. E. Blackmer. 1984. Veterinary interpretation of bulk-tank milk. Vet. Clin. North Am. Large Anim. Pract. $6: 257-268$

Hogan, J. S., and K. L. Smith. 2003. Coliform mastitis. Vet. Res. 34:507-519.

Hogan, J. S., K. L. Smith, K. H. Hoblet, D. A. Todhunter, P. S. Schoenburger, W. D. Hueston, D. E. Pritchard, G. L. Bowman L. E. Heider, B. L. Brockett, and H. R. Conrad. 1989. Bacterial counts in bedding materials used on nine commercial dairies. J. Dairy Sci. 72:250-258.

Hutchison, M. L., D. J. I. Thomas, A. Moore, D. R. Jackson, and I. Ohnstad. 2005. An evaluation of raw milk micro-organisms as markers of on farm hygiene practices related to milking. J. Food Prot. 68:764-772.

Jackson, H., and L. F. Clegg. 1965. Effect of preliminary incubation $(55 \mathrm{~F} / 18 \mathrm{hr})$ on microflora of raw bulk tank milk, with some observations on microflora of milking equipment. J. Dairy Sci. 48:407-409.

Jayarao, B. M., S. R. Pillai, A. A. Sawant, D. R. Wolfgang, and N. V Hegde. 2004. Guidelines for monitoring bulk tank milk somatic cell and bacterial counts. J. Dairy Sci. 87:3561-3573.

Karns, J. S., J. S. Van Kessel, B. J. McClusky, and M. L. Perdue. 2007. Incidence of Escherichia coli $\mathrm{O} 157: \mathrm{H} 7$ and E. coli virulence factors in US bulk tank milk as determined by polymerase chain reaction. J. Dairy Sci. 90:3212-3219.

Kelly, P. T., K. O'Sullivan, D. P. Berry, S. J. More, W. J. Meaney, E. J. O'Callaghan, and B. O'Brien. 2009. Farm management factors associated with bulk tank total bacterial count in Irish dairy herds during 2006/07. Ir. Vet. J. 62:36-42.

Mandell, G. L., J. E. Bennett, and R. Dolin. 2005. Mandell, Douglas and Bennett's Principles and Practice of Infectious Diseases. 6th ed. Churchill Livingstone, Philadelphia, PA.

Marshall, J. 1991. Differential diagnosis of high TBC. In Pract. $13: 198-201$

McKinnon, C. H., A. J. Bramley, and S. V. Morant. 1988. An in-line sampling technique to measure the bacterial contamination of milk during milking. J. Dairy Res. 55:33-40.

McKinnon, C. H., G. J. Rowlands, and A. J. Bramley. 1990. The effect of udder preparation before milking and contamination from the milking plants on bacterial numbers in bulk milk of eight dairy herds. J. Dairy Res. 57:307-318.

Mein, G. A., F. Neijenhuis, W. F. Morgan, D. J. Reinemann, J. E. Hillerton, J. R. Baines, I. Ohnstad, M. D. Rasmussen, L. Timms,
J. S. Britt, R. Farnsworth, N. Cook, and T. Hemling. 2001. Evaluation of bovine teat condition in commercial dairy herds: 1 . Noninfectious factors. Pages 347-351 in Proc. 2nd Int. Symp. Mastitis and Milk Quality, Vancouver, Canada. Natl. Mastitis Counc. Inc., Madison, WI.

Murinda, S. E., L. T. Nguyen, S. J. Ivey, B. E. Gillespie, R. A. Almeida, F. A. Draughon, and S. P. Oliver. 2002. Prevalence and molecular characterization of Escherichia coli O157:H7 in bulk tank milk and fecal samples from cull cows: A 12-month survey of dairy farms in East Tennessee. J. Food Prot. 65:752-759.

Murphy, S. C., and K. J. Boor. 2000. Trouble-shooting sources and causes of high bacteria counts in raw milk. Dairy Food Environ. Sanit. 20:606-611.

NMC. 2004. Troubleshooting Cleaning Problems in Milking Systems. Natl. Mastitis Counc. Inc., Madison, WI.

Padhye, N. V., and M. P. Doyle. 1991. Rapid procedure for detecting enterohemorrhagic Escherichia coli O157:H7 in food. Appl. Environ. Microbiol. 57:2693-2698.

Pagano, M., and K. Gauvreau. 2000. Principles of Biostatistics. 2nd ed. Duxbury Press, Belmont, CA.

Palmer, J. 1980. Contamination of milk from the milking environment. Pages 16-21 in Factors Influencing the Bacteriological Quality of Raw Milk. IDF Bulletin, document 120. International Dairy Federation, Brussels, Belgium.

Palta, M. 2003. Quantitative Methods on Population Health: Extensions of Ordinary Regression. John Wiley \& Sons, Hoboken, NJ.

Panes, J. J., and S. B. Thomas. 1968. Psychrotrophic coli-aerogenes bacteria in refrigerated milk: A review. J. Appl. Bacteriol. $31: 420-425$

Pantoja, J. C. F., D. J. Reinemann, and P. L. Ruegg. 2009. Associations among milk quality indicators in raw bulk milk. J. Dairy Sci. 92:4978-4987.

Reinemann, D. J., G. A. Mein, D. R. Bray, D. Reid, and J. S. Britt. 1997. Troubleshooting high bacteria counts in farm milk. Pages 65-79 in Natl. Mastitis Counc. 36th Annual Mtg. Proc., Albuquerque, NM. Natl. Mastitis Counc. Inc., Madison, WI.

Reinemann, D. J., A. C. L. Wong, and E. Rabotski. 1993. Interaction of chemical, thermal and physical actions on the removal of bacteria from milk contact surfaces. ASAE paper No. 933536. Int. Winter Mtg. Am. Soc. Agric. Eng., Chicago, IL.

Rysanek, D., and V. Babak. 2005. Bulk tank milk somatic cell count as an indicator of the hygiene status of primary milk production. J. Dairy Res. 72:400-405.

Sanderson, M. W., J. M. Sargeant, D. G. Renter, D. D. Griffin, and R. A. Smith. 2005. Factors associated with the presence of coliforms in the feed and water of feedlot cattle. Appl. Environ. Microbiol. 71:6026-6032

SAS Institute. 2009. SAS/STAT 9.2 User's Guide. 2nd ed. SAS Institute Inc., Cary, NC.

Schreiner, D. A., and P. L. Ruegg. 2003. Relationship between udder and leg hygiene scores and subclinical mastitis. J. Dairy Sci $86: 3460-3465$.

Thomas, S. B., R. G. Druce, and M. Jones. 1971. Influence of production conditions on the bacteriological quality of refrigerated farm bulk tank milk-A review. J. Appl. Bacteriol. 34:659-677.

Thomas, S. B., R. G. Druce, and K. P. King. 1966. The microflora of poorly cleansed farm dairy equipment. J. Appl. Bacteriol. 29:409-422.

Van Kessel, J. S., J. S. Karns, L. Gorski, B. J. McCluskey, and M. L. Perdue. 2004. Prevalence of Salmonellae, Listeria monocytogenes and fecal coliforms in bulk tank milk on US dairies. J. Dairy Sci. $87: 2822-2830$

Van Werven, T., E. N. Noordhuizen-Stassen, A. J. J. M. Daemen, Y. H. Schukken, and C. Burvenich. 1997. Preinfection in vitro chemotaxis, phagocytosis, oxidative burst, and expression of CD11/CD18 receptors and their predictive capacity on the outcome of mastitis induced in dairy cows with Escherichia coli. J. Dairy Sci. 80:67-74.

Zadoks, R. N., B. E. Gillespie, H. W. Barkema, O. C. Sampimon, S. P. Oliver, and Y. H. Schukken. 2003. Clinical, epidemiological and molecular characteristics of Streptococcus uberis infections in dairy herds. Epidemiol. Infect. 130:335-349. 